Islam and Christianity 
This page intentionally left blank 


\section{Islam and Christianity}

Theological Themes in Comparative Perspective

John Renard

口

UNIVERSITY OF CALIFORNIA PRESS

Berkeley · Los Angeles · London 
University of California Press, one of the most distinguished university presses in the United States, enriches lives around the world by advancing scholarship in the humanities, social sciences, and natural sciences. Its activities are supported by the UC Press Foundation and by philanthropic contributions from individuals and institutions. For more information, visit www.ucpress.edu.

University of California Press

Berkeley and Los Angeles, California

University of California Press, Ltd.

London, England

(C) 20 I I by The Regents of the University of California

\section{Library of Congress Cataloging-in-Publication Data}

Renard, John, I944-.

Islam and Christianity : theological themes in comparative perspective/ John Renard.

p. $\mathrm{cm}$.

Includes bibliographical references and index. ISBN 978-0-520-25508-I (cloth, alk. paper) ISBN 978-0-520-26678-o (pbk., alk. paper)

I. Islam-Relations-Christianity. 2. Christianity and other religions-Islam. 3. Islam-Doctrines. 4. Theology, Doctrinal. I. Title.

BPI72.R462 2OII

$297.2^{\prime} 83-\mathrm{dc} 22$

2010023443

Manufactured in the United States of America

\begin{tabular}{|c|c|c|c|c|c|c|}
\hline I9 & I7 & I6 & I5 & I4 & I3 & I 2 \\
\hline 9 & 8 & 6 & 5 & 4 & 2 & I \\
\hline
\end{tabular}

This book is printed on Cascades Enviro Ioo, a I00\% post consumer waste, recycled, de-inked fiber. FSC recycled certified and processed chlorine free. It is acid free, Ecologo certified, and manufactured by BioGas energy. 
In grateful memory of

my parents

George (I9II-2009) and Virginia (I9I5-2006)

and

Richard J. McCarthy, SJ (I9I3-I98I), who dedicated his professional life

to understanding and sharing the riches

of Islam's theological traditions 
This page intentionally left blank 